\title{
SINGLE PROPELLER DRONE (SINGRONE): INOVASI RANCANG BANGUN DRONE SINGLE PROPELLER SEBAGAI WAHANA PEMETAAN LAHAN BERBASIS UNMANED AERIAL VEHICLE (UAV)
}

\author{
Mohammad Giffari Anta Pradana, Ridho Prasakti, Singgih Bekti Worsito, Nuryake Fajaryati \\ Prodi Pendidikan Teknik Elektronika, Jurusan Pendidikan Teknik Elektronika FT UNY \\ Email: giffariamizade@gmail.com
}

\begin{abstract}
ABSTRAK
Dewasa ini, teknologi sebagai faktor memberikan kontribusi yang signifikan dalam peningkatan kualitas hidup manusia. Salah satu teknologi yang berkembang saat ini adalah drone. Drone adalah pesawat tanpa awak yang dikendalikan dengan sebuah remote control, di lengkapi dengan GPS sebagai navigasi, dan lock position. Pada umumnya drone digunakan untuk berbagai hal, seperti pemantauan lalu lintas, pemetaan lahan, investigasi dan sebagainya. Namun penggunaan drone dengan menggunakan banyak propeller merupakan salah satu masalah penggunaan drone. Semakin banyak propeller yang digunakan, maka masa hidup drone di udara juga akan semakin berkurang. Hal ini diarenakan baterai yang digunakan oleh wahana tersebut banyak digunakan untuk mensupply propeller agar dapat berputar. Berdasarkan permasalahan tersebut kami mempunyai gagasan untuk membuat drone yang praktis dan efesien energi, sehingga daya tempuhnya dapat lebih lama, karena penggunaan baterai yang hemat yaitu SINGRONE Inovasi Rancang Bangun Drone Single Propeller sebagai Wahana Pemetaan Lahan Berbasis UAV. Dengan potensi perkembangan tekonologi tersebut dirasa drone merupakan objek yang dibutuhkan oleh masyrakat Indonesia, terutama dalam hal pemetaan lahan
\end{abstract}

Kata kunci: Drone, Pemetaan, Propeller

\section{PENDAHULUAN}

Teknologi sebagai faktor yang memberikan kontribusi yang signifikan dalam peningkatan kualitas hidup dan pembangunan ekonomi terlihat dari fenomena terjadinya proses transisi perekonomian dunia yang semula berbasiskan pada sumber daya (resources-based economy), menjadi perekonomian yang berbasiskan pengetahuan (knowladge-based economy). Seiring dengan majunya peradaban manusia beserta segala teknologi dan kegiatan pembelajarannya, meng-haruskan pendidik untuk menguasai segala keahlian dari menggunakan, meneliti, dan mengajarkan peralatan-peralatan penunjang pembelajaran yang selalu berkembang. Berbagai perlombaan mengenai kompetensi keahlian baik teknis maupun non-teknis telah banyak diselenggarakan di berbagai wilayah diseluruh Indonesia demi meningkatkan pengembangan teknologi serta dapat menjadi ajang atau program kekreativitasan mahasiswa.

Drone adalah pesawat tanpa awak yang dikendalikan dengan sebuah remote control, dilengkapi dengan GPS sebagai navigasi, dan lock position. Remot drone dapat di gantikan dengan smartphone menggunakan aplikasi yang dapat di unduh di playstore menggunakan koneksi wifi direct, Maupun koneksi sinyal wireless. Saat ini drone sudah banyak beredar dipasaran. Kebanyakan drone yang beredar di pasaran adalah drone dengan tipe tricopter, quad copter, heksa copter, okta copter dan sebagainya. Pada umumnya drone digunakan untuk berbagai hal, seperti pemantauan lalu lintas, pemetaan lahan, investigasi dan sebagainya. Namun penggunaan drone atau pesawat tanpa awak dengan menggunakan banyak propeller merupakan salah satu masalah penggunaan drone. Semakin banyak propeller yang digunakan, maka masa hidup drone di udara juga akan semakin berkurang. Karena baterai yang digunakan oleh wahana tersebut banyak digunakan untuk mensupali propeller agar dapat berputar.

Berdasarkan permasalahan tersebut kami mempunyai gagasan untuk membuat drone 
yang praktis dan efesien energi, sehingga daya tempuhnya dapat lebih lama, karena penggunaan baterai yang hemat yaitu SINGRONE Inovasi Rancang Bangun Drone Single Propeller sebagai Wahana Pemetaan Lahan Berbasis UAV. Dengan potensi perkebangan tekonologi tersebut dirasa drone merupakan objek yang dibutuhkan oleh masyrakat Indonesia, terutama dalam hal pemetaan lahan.

Singrone bekerja dengan meman-faatkan hanya satu propeller untuk membuat wahana terbang di udara. Dengan satu propeller maka daya baterai dapat digunakan untuk terbang lebih lama, terutama dalam pemetaan lahan yang biasanya membutuhkan waktu yang relatif lama. Singrone dilengkapi juga dengan GPS untuk menambah fitur dan fungsi navigasi yang lebih luas untuk menyisir area lahan yang akan dipetakan.

\section{METODE}

Single propeller drone dimulai pada bulan Juni 2016. Tempat pelaksanaan di bengkel robotika fakultas teknik UNY dan pengambilan data dilaksanakan pada indoor dan outdoor sekitar Fakultas Teknik Universitas Negeri Yogyakarta. Pelak-sanaan ini melalui beberapa metode yang teratur dan terstruktur.

Metode yang digunakan dalam pengembangan alat ini mengikuti model Linear Sequential Model (LSM) yang terdiri dari 5 tahapan yang berulang yaitu tahap analisis dan studi literatur, desain/ perancangan sistem, perakitan hardware (assembly hardware), pengkodean (coding-software), dan pengujian. Kelima tahapan ini akan berulang hingga dipenuhinya kondisi ideal yaitu sistem berfungsi dengan baik sesuai yang direncanakan.

\section{Analisis dan Studi Literatur}

Pada tahap analisis dan studi literatur dilakukan dengan mencari data primer dan sekunder. Pengambilan data primer dilakukan melalui wawancara dan observasi langsung dengan tim dari robot KRTI UNY. Sedangkan data sekunder diperoleh dari buku, jurnal, maupun artikel online. Dalam tahapan ini, dilaksanakan studi literatur mengenai karakteristik mikrokontoler dan sensor yang digunakan dalam pembuatan drone, sistem mekanik serta analisis propeller yang akan digunakan. Dari studi tersebut diperoleh data spesifikasi motor brushless.

\begin{tabular}{|c|c|c|c|c|c|c|c|c|c|}
\hline Model & Volta & $K V(i p m / v)$ & $\begin{array}{l}\text { Max } \\
\text { pull }\end{array}$ & Weight & Motor size & Shaft Size & $\begin{array}{l}\text { Max } \\
\text { power }\end{array}$ & $\begin{array}{l}E S C \\
\text { (A) }\end{array}$ & Batteray/Prop \\
\hline D2826-6 & \multirow{4}{*}{$\begin{array}{l}7.4- \\
1.1 \mathrm{~V}\end{array}$} & 2200 & $960 \mathrm{~g}$ & \multirow{4}{*}{$50 \mathrm{~g}$} & \multirow{4}{*}{$=27.7^{*} 26 \mathrm{~mm}$} & \multirow{4}{*}{ - $3.175 \mathrm{x} 41 \mathrm{~mm}$} & $\begin{array}{l}342 \\
\text { watt }\end{array}$ & \multirow{4}{*}{$40 \mathrm{~A}$} & $\begin{array}{l}\text { LiPox } 2 / 7 \times 4 \\
\text { LiPox } 3 / 7 \times 3\end{array}$ \\
\hline D2826-10 & & 1400 & $780 \mathrm{~g}$ & & & & $\begin{array}{l}205 \\
\text { watt }\end{array}$ & & $\begin{array}{c}\text { LiPox } 2 / 9 \times 4.7 \\
\text { LiPox } 3 / 7 \times 4\end{array}$ \\
\hline D2826-13 & & 1000 & $660 \mathrm{~g}$ & & & & $\begin{array}{l}150 \\
\text { watt }\end{array}$ & & $\begin{array}{l}\text { LiPox } 2 / 11 \times 7 \\
\text { LiPox } 3 / 10 \times 5\end{array}$ \\
\hline D2826-15 & & 930 & $645 g$ & & & & $\begin{array}{l}130 \\
\text { watt }\end{array}$ & & $\begin{array}{l}\text { LiPox } 2 / 12 \times 6 \\
\text { LiPox } 3 / 11 \times 7\end{array}$ \\
\hline
\end{tabular}

Gambar 1. Spesifikasi Motor Brushless 


\section{Desain dan Perancangan Sistem}

Pada proses ini dibagi menjadi 3 tahap yaitu desain bentuk mekanik drone, desain elektronik, dan desain program pengendali untuk sistem elektronik yang dibuat. Pada pembuatan desain mekanik menggunakan software desain 3D (Solidworks 2014) agar desain drone dapat memperhatikan ukuran dan bentuk secara presisi sehingga saat membuat rangka drone secara nyata akan terbentuk sesuai dengan yang diharapkan.

Secara garis besar sistem terdiri dari tiga bagian utama yaitu: 1) Sensor, dan remote control, sebagai input atau masukan. 2) Mikrokontroler dan GUI sebagai kontrol dan monitoring dari Singrone. 3) Propeller dan servo sebagai output.

Perancangan program kendali menggunakan software Arduino yang digunakan dalam memogram sistem kendali pada kontroler elektronik yang telah dirancang sebelumnya. Dalam membuat rancangan program harus dapat memperhitungkan perubahan-perubahan data dari semua sensor dan masukan agar dapat mengendalikan 4 buah servo dan 1 buah motor brushless. Respon yang diharapkan dalam program yang dibuat adalah agar drone dapat terbang stabil dan dapat dikendalikan menggunakan remote.

\section{Perakitan Hardware}

Implementasi perakitan hardware berfungsi untuk memuat pemasangan mekanis Singrone, pemasangan elektronik berupa sensor, kontroler, servo, esc(electronic speed controller) dan motor brushless. Dalam pemasangan single propeller drone, pemasangan elektronik dan pemasangan mekanik dapat efektif dan efisien serta dapat bekerja secara ideal dan siap diuji cobakan.

\section{Pengkodean}

Pengkodean pada kontroler menggunakan software Arduino. Pengkode-an yang telah dibuat akan diuji dan di cek respon dari sensorsensor dengan mengamati GUI (Gaphical User Interface). Informasi yang tertampildi dalam GUI berupa nilai keluaran dari Sensor Gyro (Sensor Kemiringan), Sensor Accelero (Sensor Percepatan), Sensor Magnetometer (Sensor
Kompas), Sensor Barometer (Sensor Tekanan untuk ketinggian) dan nilai Yaw, Pitch, Roll dari Single Propeller Drone. Selain nilai dari sensor tertampil juga nilai dari servo dan motor brushless sebagai keluaran dari kontroler. Kontroler dan GUI dapat bekerja secara terintegrasi dan dapat bekerja sesuai yang diharapkan dengan menggunakan sambungan serial dengan converter USB FTDI.

\section{Pengujian Perangkat}

Setelah pembuatan rangka, pemasangan elektronik, dan pengkodean selesai selanjutnya adalah tahap pengujian, pada tahap ini dilakukan pengujian pada Singrone. Pengujian dilakukan baik didalam maupun diluar ruangan, untuk mengecek respon kerja sensor, servo, motor brushless dan remote control. Pada tahap percobaan dilakukan untuk mengetahui dan menguji kekurangan dalam Singrone sehingga Singrone dapat dievaluasi dan diperbaiki menjadi lebih baik pada percobaan selanjutnya.

\section{HASIL DAN PEMBAHASAN}

Pada versi pertama bentuk dari Singrone terlihat kaku dan cukup rapuh karena susunan rangka utama kurang memiliki penahan tekanan pada sayap Singrone. Singrone memiliki sirip sebanyak 4 buah yang digerakan oleh 4 buah servo. Sebagai pengangkat drone menggunakan motor brushless dengan kemampuan sebesar 2200 KV dan ESC (Electronic Speed Controller) sebesar 40 Ampere. Kontroler utama menggunakan Arduino Nano dan sensor MPU6050 (Sensor Gyro dan Accelero 6 Axis). Receiver remote menggunakan frekuensi 2,4 $\mathrm{GHz}$ dengan banyak channel sebanyak 6 channel. Baterai yang digunakan adalah batterai LiPo (Lithium Polymer) 3 Cell dengan kapasitas sebesar $1300 \mathrm{mAH}$. Singrone versi pertama ini dilakukan beberapa uji coba di dalam ruangan dan diluar ruangan. 


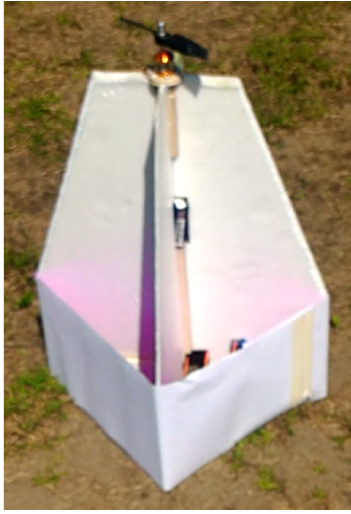

Gambar 2. Singrone V_1

Percobaan pertama dilakukan di dalam ruangan guna menguji kecepatan, arah motor brushless dan sirip agar sesuai dengan arah perputaran yang dikendalikan dengan remote. Selain itu diuji juga respo $\mathrm{n}$ antara remote dan drone terjadi jeda waktu pergerakan atau delay antara perintah yang dikirim dari remote dan respon dari Singrone. Pengujian lain juga dilakukan seperti di hentakan dan diputar-putar untuk menguji pemasangan mekanik dan elektronik agar tidak akan ada yang lepas pada saat drone terbang, karena jika drone terbang dan ada bagian yang lepas maka kesetabilan dan fungsi kerja dari drone akan rusak dan tidak stabil sehingga sulit dikendalikan bahkan jatuh.

Percobaan di luar ruangan dilakukan dibeberapa tempat, yang pertama dilakukan di halaman tetapi saat dilakukan percobaan Singrone masih kurang stabil pada saat terbang. Selanjutnya dilakukan di lapangan luas sehingga percobaan dapat lebih maksimal dengan lebih sedikit gangguan, gangguan yang ada pada lapangan luas adalah angin yang terkadang cukup besar yang dapat mengganggu keseimbangan Singrone saat uji coba terbang, sehingga sebelum melakukan ujicoba cek terlebih dahulu keadaan angin dan posisi agar bisa melakukan take off dengan benar. Pada pengujian pertama di lapangan luas drone dapat terbang dengan cukup stabil dan tinggi, akan tetapi angin yang cukup besar menyebabkan Singrone menjadi kehilangan keseimbangan. Setelah kehilangan keseimbangan Singrone dikendalikan menggunakan remote untuk mengembalikan posisi agar seimbang dan stabil lagi tetapi pengaruh ukuran sirip dan pergerakan servo terlalu besar, sehingga pergerakan Singrone menjadi teralu responsif dan bertambah sulit untuk dikendalikan.

Ukuran sirip penggerak dan pergeseran servo pengendali sirip sangat penting dan berpengaruh terhadap pergerakan dan respon kendali dari Singrone, pada percobaan pertama di lapangan pengaruh sirip terlalu besar sehingga saat dikendalikan dengan remote drone sulit dikendalikan.

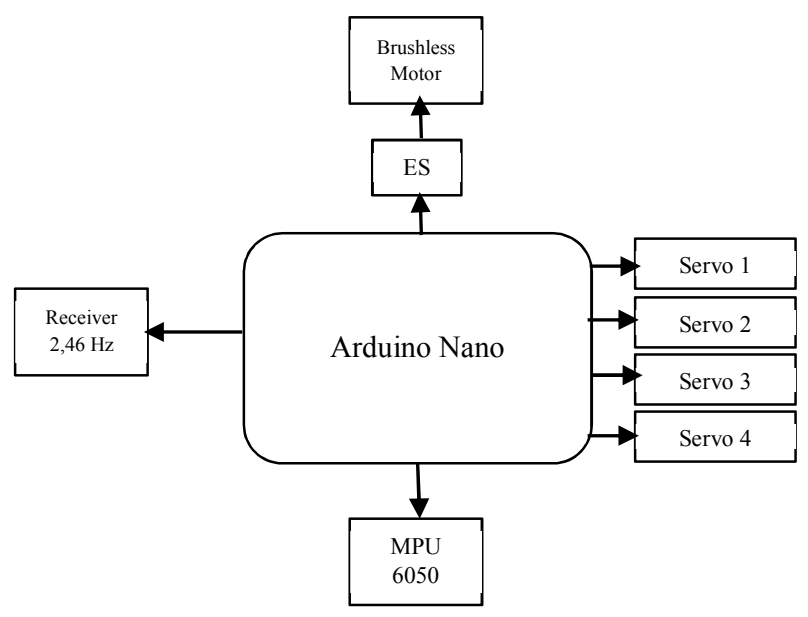

Gambar 3. Blok rangkaian Elektronik Singrone V_1

Singrone versi dua dibuat karena pada versi pertama mengalami kerusakan. Singrone versi dua dibuat dengan bentuk dasar bulat dengan beberapa rangka penopang sehingga rangka Singrone versi dua menjadi cukup kuat. Jumlah sirip penggerak yang digunakan bejumlah 4 buah dengan digerakan dengan 4 buah servo.

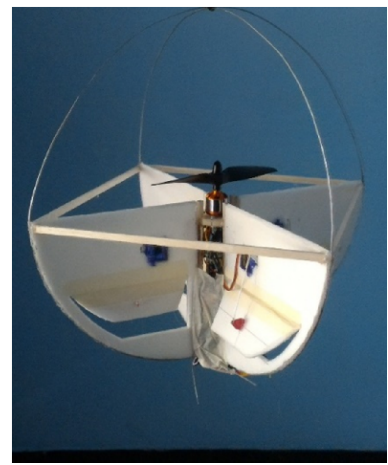

Gambar 4. Singrone V 2 
Untuk mengangkat Singrone versi dua menggunakan motor brushless dengan spesifikasi $2200 \mathrm{KV}$ dan ESC (Electronic Speed Controller) sebesar 40 Ampere. Propeler yang digunakan memiliki spesifikasi 7" x 5. Baterai yang digunakan adalah baterai LiPo dengan kapasitas $1300 \mathrm{mAH} 3$ cell. Kontroler yang digunakan adalah Multiwii 2.6, sensor yang digunakan dalah MPU6050, HMC5883L (Magnetometer 3 axis), BMP085 (Sensor tekanan) yang kesemua sensorya telah terpasang di dalam Multiwii 2.6. Pada Singrone versi dua dilakukan percobaan di dalam ruangan dan juga di luar ruangan.

Pada percobaan didalam ruangan diuji respon sensor dan servo terhadap perubahan pergerakan dari Singrone. Nilai-nilai perubahan data dan respon dari sensor dipantau dan diatur menggunakan GUI menggunakan penghubung USB FTDI dari Singrone ke laptop. Pengaturan yang dilakukan mengatur respon dari pergerakan servo dan arah sirip sudah sesuai dengan rancangan atau belum. Dengan mengatur respon sensor terhadap servo maka dapat dihasilkan kestabilan pada drone, sehingga drone dapat terbang dengan stabil dengan membawa kamera tanpa banyak bergetar dan berputar. Saat di dalam ruangan Singrone versi dua dicoba dengan cara digantung sehingga dapat diuji Percobaan diluar ruangan dilakukan untuk menguji respon kestabilan dari drone dengan terbang dan mendarat dengan baik.

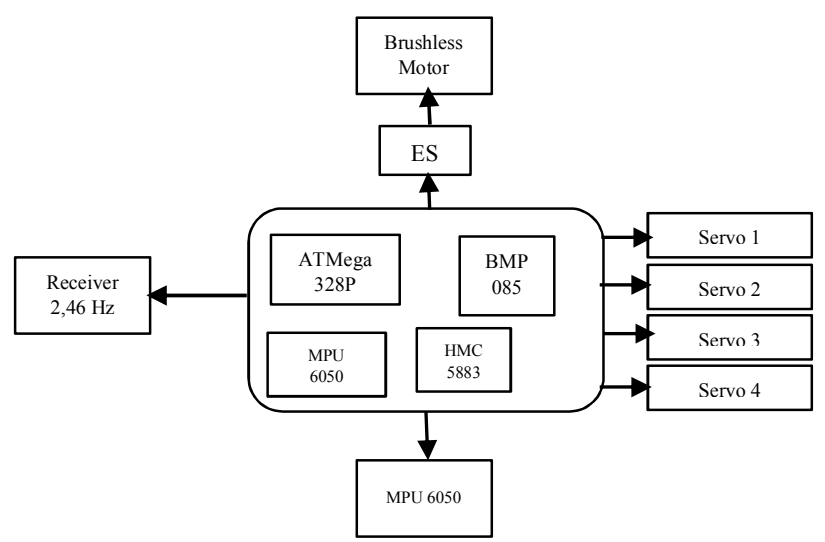

Gambar 5. Blok rangkaian Elektronik Singrone V_2

Pada Singrone versi dua rangka yang dibuat lebih kuat dan lebih ringan. Rangka menjadi lebih kuat karena menggunakan penahan rangka dari kayu balsa dan kawat. Sehingga walaupun terkena benturan ringan tidak akan langsung rusak. Selain itu beban rangka lebih ringan dibandingkan dengan versi pertama sehingga dapat membuat drone lebih efisien. Sedangkan dari segi elektronik, pengkabelan menjadi lebih rapi dan tertata. Sensor sensor yang digunakan pada Singrone versi dua juga lebih lengkap dan terpadu pada satu buah rangkaian sehingga mengurangi noise dan gangguan sambungan.

Tabel 1. Perbandingan Singrone V1 dan V2

\begin{tabular}{|l|c|c|}
\hline & Singrone V-1 & Singrone V-2 \\
\hline Berat & 825 gram & 630 gram \\
\hline Propeller & $7 "$ x 5 & $7 "$ x 5 \\
\hline Motor Brushless & $2200 \mathrm{kV}$ & $2200 \mathrm{kV}$ \\
\hline Baterai & $1300 \mathrm{mAH}$ & $1300 \mathrm{mAH}$ \\
\hline Sensor Gyro Accelero & MPU6050 & MPU6050 \\
\hline Sensor Barometer (Tekanan) & $\mathrm{x}$ & BMP085 \\
\hline Sensor Magnetometer (Arah) & $\mathrm{x}$ & HMC5883L \\
\hline
\end{tabular}




\section{SIMPULAN}

Berdasarkan hasil dan pembahasan yang telah dipaparkan di atas, maka dapat disimpulkan sebagai berikut: Berdasarkan hasil dari pelaksanaan dapat disimpulkan bahwa desain alat, desain sistem, dan Singrone sebagai inovasi rancang bangun drone single propeller sebagai wahana pemetaan lahan berbasis UAV smart trainer for archer dengan komponen utama sensor, remot kontrol, mikrokontroller, GUI, propeller dan servo.

Dari hasil pengujian didapatkan bahwa Drone dengan satu propeller dapat terbang secara seimbang meskipun masih sulit dikendalikan, sehingga penelitian ini dibutuhkan berbagai teori dan percobaan kembali agar bisa disempurnakan.

Dari data tersebut juga dapat disimpulkan keunggulan Singrone versi dua dibandingkan versi sebelumnya yaitu : (1) Singrone versi dua dibuat dengan bentuk dasar bulat dengan beberapa rangka penopang sehingga rangka Singrone versi dua menjadi cukup kuat dibanding versi pertama dari Singrone terlihat kaku dan cukup rapuh karena susunan rangka utama kurang memiliki penahan tekanan pada sayap Singrone. (2) Singrone versi dua menggunakan sensor berometer dan magnetometer sehingga pada saat drone terbang lebih stabil atau seimbang dibandingkan Singrone versi sebelumnya.

Singrone dapat dikembangkan kembali dari segi tampilan fisik serta mekanik sehingga kedepanya, Singrone dapat terbang dengan stabil dan mudah dikendalikan. Jadi, walaupun bekerja dengan memanfaatkan hanya satu propeller untuk membuat wahana terbang diudara. Singrone inovasi rancang bangun Drone Single Propeller sebagai wahana pemetaan lahan berbasis UAV ini dapat bekerja sesuai dengan harapan.

\section{DAFTAR RUJUKAN}

Budiawan, Tiyo, Imam Santosa, Ajub Ajulian Zahra. Mobile Tracking GPS (Global Positioning System) Melalui
SMS (Short Message Service). Semarang: Universitas Diponegoro.

Jonser Sihotang. 2009. AEROMODELLING RESEARCH AND DEVELOPMENT CENTER. Universitas Guna Darma. http://www.gunadarma.ac.id/library/articl es/graduate/civilengineering/2009/Artike 1_20303024.pdf. Pada 23 Oktober 2015.

Khedi. 2015. Beberapa Fungsi Drone Komersial yang Perlu Anda Ketahui. Diakses dari: http://techno.khedisfile.com/2015/07/31 /beberapa-fungsi-drone-komersialyang-perlu-anda-ketahui/. Pada 10 April 2016.

Muzakhim, Azam. 2011. Telemetri dan Telekontrol antar Mikrokontroller Menggunakan Xbeepro Wireless. Jurnal Elektro. Volume 09 Nomor 02 hal 6.

Syahrul. _. Karakteristik dan Pengontrolan Servomotor. Jurnal Bidang Rekayasa. Volume 8 Nomor 2 hal 143. 